\title{
Orthodontic Use of Documentation in Identification of a Skeletonized Body in Legal Dental Practice
}

\author{
Uso de Documentación de Ortodoncia en la Identificación de \\ un Cuerpo Esqueletizado en la Práctica Odontológica Legal
}

\begin{abstract}
Andrea Sayuri Silveira Dias Terada*; Laís Gomes de Araujo“; Luiz Renato Paranhos ${ }^{\star * *}$; Teresa Cristina Pantozzi Silveira ${ }^{* * * *}$; Marco Aurélio Guimarães ${ }^{*+* k}$ \& Ricardo Henrique Alves da Silva ${ }^{* * * * *}$
\end{abstract}

TERADA, A. S. S. D.; ARAUJO, L. G.; PARANHOS, L. R.; SILVEIRA, T. C. P.; GUIMARÃES, M. A. \& SILVA, R. H. A. Orthodontic use of documentation in identification of a skeletonized body in legal dental practice. Int. J. Odontostomat., 8(1):41-46, 2014.

ABSTRACT: The analysis of dental records is an essential tool for human identification. The present study aimed to highlight the importance of dental records for identification of skeletonized bodies. In form of conclusion, the method of dental identification using dental records represents a valid option for forensic dentistry.

KEY WORDS: forensic dentistry, human identification, case report.

\section{INTRODUCTION}

Forensic dentistry is closely related to human identification in situations where other means are not indicated or are not applicable, as in cases of mutilated, decomposed or fragmented bodies (Almeida et al., 2010). The identification by dental characteristics is a comparative methodology, which involves a comparison of records obtained with antemortem and postmortem records (Silva et al., 2009a). This comparison can be made between dental and pathological characteristics, and treatments presented in the dental arches of the victim's data (Vanrell, 2008). The successful application of dentistry in human identification is dependent of the achievement of adequate clinical records containing information of the dental elements.

In this context, the aim of this paper is to emphasize the importance of dental records to identify human through a forensic case report, conducted from the anthropological study of the profile, associated with the analysis of peculiarities on orthodontic documentation.

\section{CASE REPORT}

A skeleton was found in a reed bed in the region of Ribeirão Preto, São Paulo State, Brazil, which was referred to the Centre of Forensic Medicine (CEMEL) belonging to the Faculty of Medicine of Ribeirão Preto (FMRP), University of São Paulo (USP) for forensic investigation to determine the cause of death and attempt to obtain the identification of the individual.

First, the anthropological analysis revealed that the cause of death was due to trauma caused by a perforating object, suggesting a projectile from a firearm. The anthropological profile indicated that it was a male, of Caucasian ancestry, aged approximately between 19 and 26 years, height between $1.85 \mathrm{~m}$ and $1.94 \mathrm{~m}$ and dexterous. CEMEL noted that there was a family looking for an individual missing, with the features and information consistent with those found in the forensic analysis.

The relatives were asked to search and bring the dental records for the continuity of the forensic examination. Therefore, the orthodontic documentation

\footnotetext{
Master of Science, Ribeirão Preto School of Dentistry, University of São Paulo, Ribeirão Preto, Brazil.

** Master Degree Studant, Ribeirão Preto School of Dentistry, University of São Paulo, Ribeirão Preto, Brazil.

*** PhD, Professor of Oral Biology Program at USC Dental, Sacred Heart University, Bauru, Brazil

*m* Lab Technician, CEMEL, Ribeirão Preto Medicine School, University of São Paulo, Ribeirão Preto, Brazil.

*..** PhD, Professor of Legal Medicine, Ribeirão Preto Medicine School, University of São Paulo, Ribeirão Preto, Brazil.

${ }^{* *+* * *+}$ PhD, Professor of Forensic Dentistry, Ribeirão Preto School of Dentistry, University of São Paulo, Ribeirão Preto, Brazil.
} 
was referred (composed of extra-oral photographs, panoramic radiography and dental casts of the maxilla and mandible) as shown in Figure 1, which were sent to the forensic dental examination in the Faculty of Dentistry of Ribeirão Preto (FORP) of USP, along with the victim's skull and mandible (Fig. 2).

The comparative analysis of the orthodontic antemortem documentation associated with the clinical and radiographic examination conducted postmortem, allowed observation of the following compatible dental particularities: lacking teeth, 36 (lower left first molar), 38 (lower left third molar), 46 (first lower right molar) and 47 (lower right second molar) (Fig. 3), the dental cast of the jaw, presented supernumerary tooth in the lingual region of teeth 32 (lower left lateral incisor) and 33 (lower left canine), and in the lingual region of the jaw, there was an empty alveolus, indicating the postmortem loss of a supernumerary tooth (Fig. 4). Tooth 18 (upper right third molar) had a loss of tooth substance in the occlusal surface that was also observed in panoramic radiography compared antemortem as in postmortem (Fig. 5), tooth 11 (upper right central incisor) in both antemortem and postmortem radiographs had a intra-radicular post and a partially obturated root canal (third apical) (Fig. 6), besides a rehabilitation treatment (Fig. 7); tooth 34 is rotated (left premolar) in both the dental casts as in the mandible (Fig. 8).

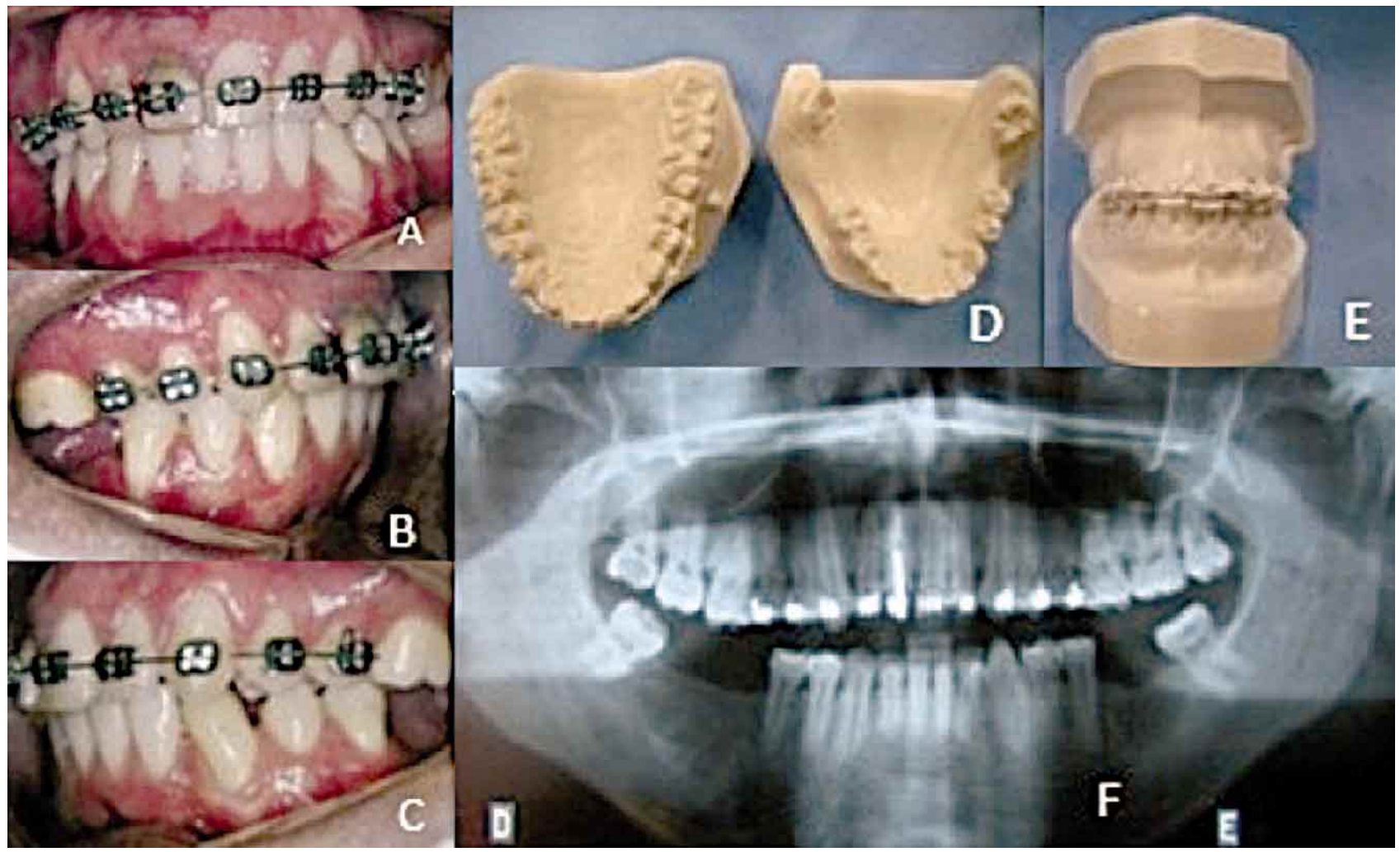

Fig. 1. Orthodontic documentation forwarded: intraoral photographs with front view $(A)$, right lateral views $(B)$ and left $(C)$; dental cast of the maxilla and mandible (D) models in occlusion (E) and panoramic radiograph (F).

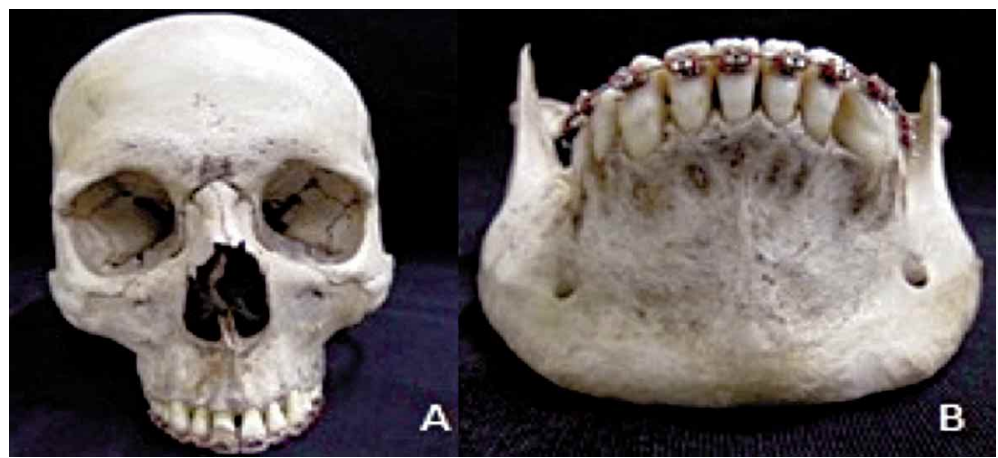

Fig. 2. Assessed material skull $(A)$ and jaw (B). 


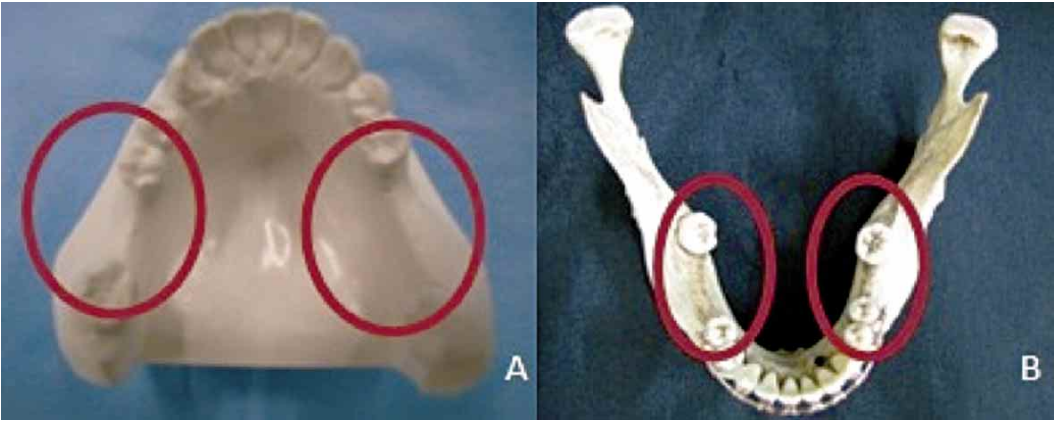

Fig. 3. Forensic dental comparison: absence of dental elements in the dental cast $(A)$, the jaw $(B)$.

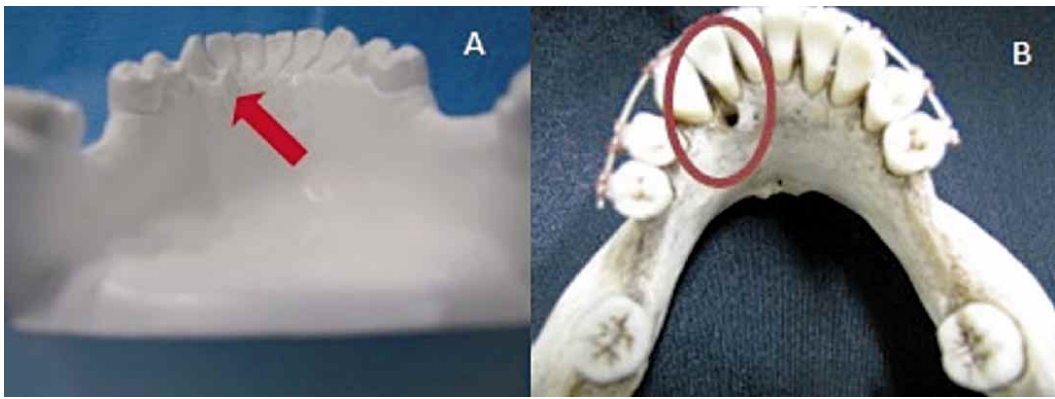

Fig. 4. Forensic dental comparison: the presence of supernumerary tooth $(A)$ and an empty alveolus indicating the loss of postmortem supernumerary tooth in the jaw $(B)$

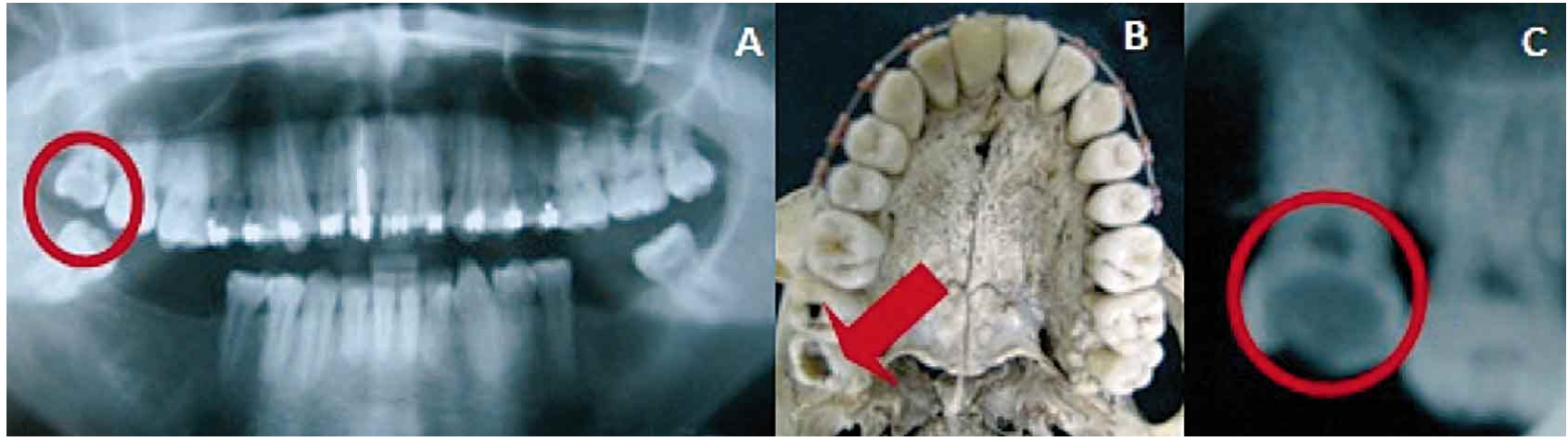

Fig. 5. Forensic dental comparison: the antemortem panoramic radiograph, radiolucent on the 18 suggesting loss of tooth substance (A) loss of tooth substance in tooth 18 observed in the maxilla (B) in postmortem periapical radiography, a radiolucent area in the 18 tooth suggesting loss of tooth substance.

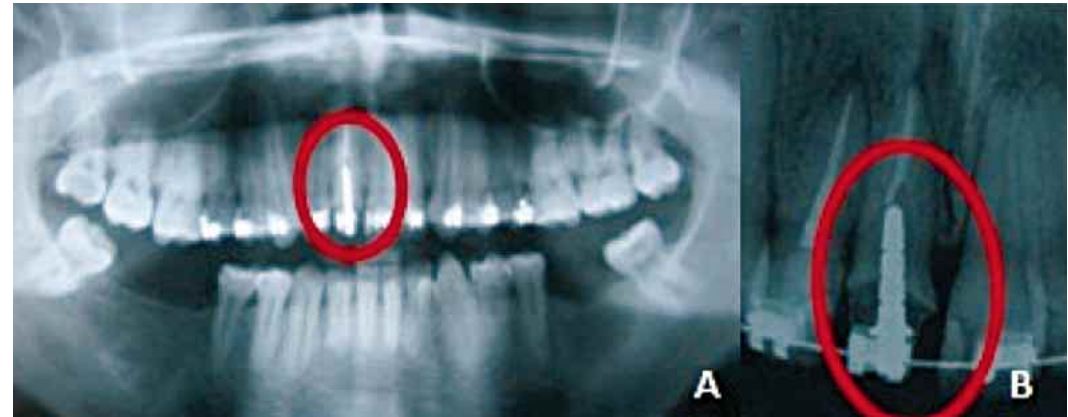

Fig. 6. Forensic dental comparison: presence of an intra-radicular post and a partially obturated root canal (apical) in both antemortem panoramic (A) and in the post mortem periapical radiography (B). 


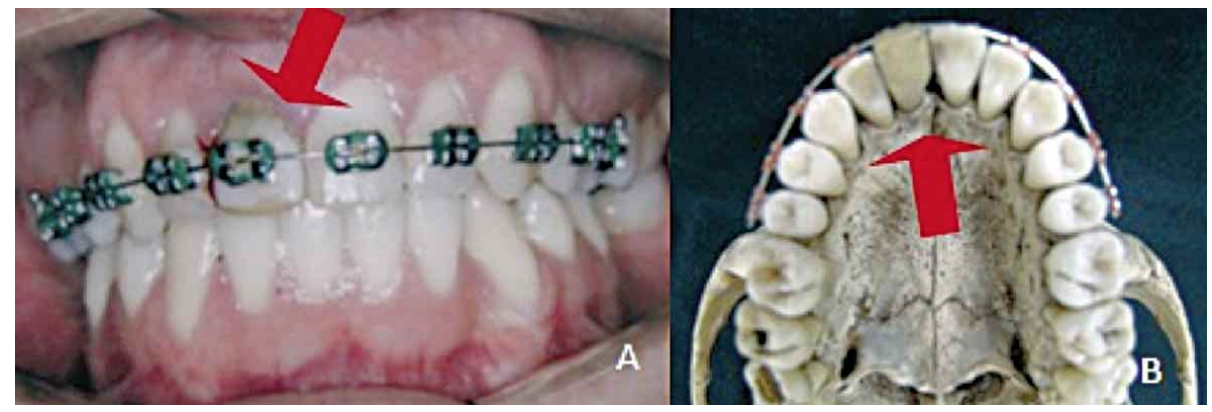

Fig. 7. Forensic dental comparison: rehabilitative treatment in the 11 tooth observed in antemortem photograph $(\mathrm{A})$ and in the mandible $(\mathrm{B})$.

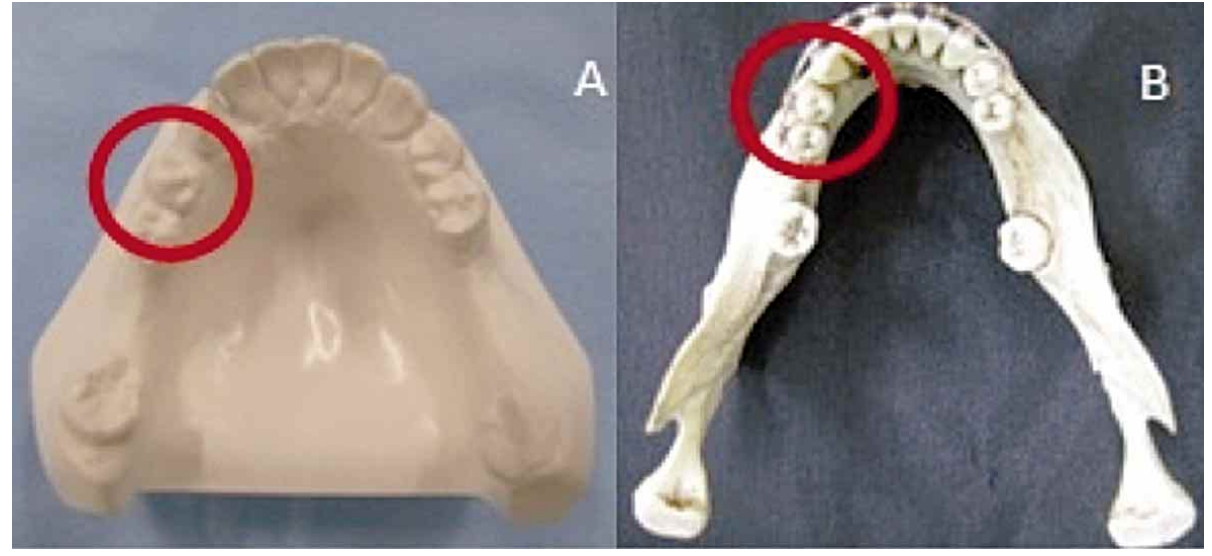

Fig. 8. Presence of 34 tooth rotated in both the dental cast $(A)$ and in the mandible (B).

\section{DISCUSSION}

The viability of the analysis of dental characteristics as an identification method has been shown and reported in literature (Caputo et al., 2011; Carvalho et al., 2008; Silva et al., 2008; Silva et al., 2011). The fact that there aren't two people with the same dental characteristics (Vanrell), including the strength properties of the teeth, which enables them to withstand a number of degrading conditions (Almeida et al.), the dental analysis for human identification is a routine practice in cases of skeletonized bodies or those in an advanced stage of decomposition. Therefore, the identification of this report was accomplished by obtaining the documentation related to the dental treatments of the disappeared person.

Dental records are a document of great importance in dentistry and, when properly prepared, will serve as a record for human identification (Benedicto et al., 2010). Medical records and radiographs are the most used documents
(Benedicto et al., 2010; Rothwel, 2001; Silva et al., 2011). Thus, if there is a suspect, the search for dental records containing more complete data is needed and relevant for the identification of the individual (Terada et al., 2011).

In this case, from the anthropological data a suspect was generated, the family was warned and subsequently a search was requested for the antemortem documentation that could serve as comparison in forensic identification. Despite the importance of the dental records (Benedicto et al.), absence of records is often observed this usually is a result of a family that neglects the documentation, or maintains the documentation in poor condition, presenting information considered irrelevant or incomplete for the forensic dentist work (Rothwel; Silva et al., 2011; Terada et al.).

Given the above information, it is worth highlighting the importance of dental records, which, 
in the addition to clinical contributions that they provide, allows for the monitoring of clinical care and can also serve as antemortem documentation (Benedicto et al.; Rothwel).

Because of the complexity of cases involved in orthodontic treatments, many dental data are produced to assist the dentist in the planning and execution of treatment. Typically, this documentation gathers information related to health and patient identification, containing: intra and extra-oral clinical examination, treatment plan chosen, execution of treatment, and complementary exams (Silva et al., 2011).

This documentation has great legal orthodontic validity, because it has information which may define a positive identity and an undeniable victim (Vanrell). In this case, the documentation related to the orthodontic treatment of the disappeared person, including panoramic radiographs and photographs used in the orthodontic planning, were obtained without significant distortions and satisfactory quality, allowing the qualitative aspects to be analyzed successfully.

In the forensic dental examination performed, the first stage involved the registration of the dental peculiarities presented in the dental arches. Subsequently, this second step corresponds to the search for dental records, which included the medical records (radiographs, dental casts and photographs). From this, the identification process has been completed by means of a comparison between the specific characteristics of the individual standard material with the material questioned.

In this case, several points were obtained coinciding and culminating in a positive forensic dental identification. In the positive identification, there is enough uniqueness among comparable items, getting very close to certainty, as to occur again under the same circumstances (Silva et al., 2009b)

In the dental forensic analysis there is not a correct number of points for determining a compatible identity (Acharya \& Taylor, 2003; Silva et al., $2009 \mathrm{~b}$ ). The professional should focus on the qualitative aspects of the information obtained ante and postmortem, because the conclusion about the establishment of the identity depends crucially on the quality of material found in each case. In the material in question, the discrepancies between ante and postmortem information relating to the supernumerary tooth is considered to be very specific to confirm the individual's identity when compared with the characteristics involving missing teeth.

Therefore, considering the peculiarity of the process that involves the identification of bodies in São Paulo, the identification technique in forensic dentistry using dental records, has clinical relevance and expertise, effectively and safely supporting information of performed treatments, making it a practical and reliable source of results.

\section{CONCLUSION}

The positive identification in this case was achieved by obtaining documentation related to orthodontic treatment. Analysis of antemortem dental records and characteristics found in dental arches (postmortem) associated with radiographs produced during dental forensic evaluation, had enough points of comparison to identify the individual with technical and scientific foundation. It is therefore, important that dental records be complete and accurate as evidence, in order to establish identification in a positive and uncontestable manner.

TERADA, A. S. S. D.; ARAUJO, L. G.; PARANHOS, L. R.; SILVEIRA, T. C. P.; GUIMARÃES, M. A. \& SILVA, R. H. A. Uso de documentación de ortodoncia en la identificación de un cuerpo esqueletizado en la práctica odontológica legal. Int. J. Odontostomat., 8(1):41-46, 2014.

RESUMEN: El análisis de los registros dentales es una herramienta esencial para la identificación humana. El presente estudio tuvo como objetivo destacar la importancia de los registros dentales para la identificación de los cuerpos esqueletizados. El método de identificación dental que utiliza los registros dentales, representa una opción válida para la odontología forense.

PALABRAS CLAVE: Odontología forense, identificación humana, reporte de un caso. 
TERADA, A. S. S. D.; ARAUJO, L. G.; PARANHOS, L. R.; SILVEIRA, T. C. P.; GUIMARÃES, M. A. \& SILVA, R. H. A. Orthodontic use of documentation in identification of a skeletonized body in legal dental practice. Int. J. Odontostomat., 8(1):41-46, 2014.

\section{REFERENCES}

Acharya, A. B. \& Taylor, J. A. Are a minimum number of concordant matches needed to establish identity in forensic odontology? J. Forensic Odontostomatol., 21(1):6-13, 2003.

Almeida, C. A.; Paranhos, L. R. \& Silva, R. H. A. A importância da odontologia na identificação post-mortem. Odontol. Soc., 12(2):7-13, 2010.

Benedicto, E. M.; Lages, L. H. R.; Oliveira, O. F.; Silva, R. H. A. \& Paranhos, L. R. A importância da correta elaboração do prontuário odontológico. Odonto, 18(36):41-50, 2010.

Caputo, I. G. C.; Reis, J. N.; Silveira, T. C. P.; Guimarães, M. A. \& Silva, R. H. A. Identification of a charred corpse through dental records. RSBO, 8(3):345-51, 2011.

Carvalho, C. M.; Nazar, R. J.; Moreira, A. M. C. \& Bouchardet, F. C. H. Identificação humana pelo exame da arcada dentária. Relato de caso. Arq. Bras. Odontol., 4(21):679, 2008.

Rothwell, B. R. Principles of dental identification. Dent. Clin. North Am., 45(2):253-70, 2001.

Silva, R. F.; Chaves; P.; Paranhos, L. R.; Lenza, M. A. \& Daruge Júnior, E. Use of orthodontic records in human identification. Dental Press J. Orthod., 16(2):52-7, 2011.

Silva, R. F.; Daruge Júnior, E.; Pereira, S. D. R.; Almeida, S. M. \& Oliveira, R. N. Identificação de cadáver carbonizado utilizando documentação odontológica. Rev. Odonto Ciênc., 23(1):90-3, 2008.

Silva, R. F.; Prado, M. M.; Barbieri, A. A. \& Daruge Júnior, E. Utilização de registros odontológicos para identificação humana. RSBO,6(1):95-9, 2009a.

Silva, R. F.; Prado, M. M.; Oliveira, H. C. M. \& Daruje Júnior, E. Quantos pontos de concordância são necessários para se obter uma identificação odontolegal positiva? Rev. Odontol. Univ. Cid. Sao Paulo, 21(1):63-8, 2009b.

Terada, A. S. S. D.; Leite, N. L. P.; Silveira, T. C. P.; Secchieri, J. M.; Guimarães, M. A. \& Silva, R. H. A. Identificação humana em odontologia legal por meio de registro fotográfico de sorriso: relato de caso. Rev. Odontol. UNESP., 40(4):199-202, 2011

Vanrell, J. P. Odontologia Legal e Antropologia Forense. Rio de Janeiro, Guanabara Koogan, 2008.
Correspondence to:

Andrea Sayuri Silveira Dias Terada

Faculdade de Odontologia de Ribeirão Preto - USP

Departamento de Estomatologia

Saúde Coletiva e Odontologia Legal

Área de Odontologia Legal.

Avenida do Café, s/n - Monte Alegre

CEP: $14040-904$

Ribeirão Preto/ SP,

BRAZIL

Telephone: (+55) 16 3612-4337

(+55) 16 8826-0666

Email: andrea.terada@usp.br

Received: 11-07-2013

Accepted: 17-11-2013 